\title{
ANTESEDEN NIAT MEMBELI PRODUK KOSMETIK RAMAH LINGKUNGAN THE FACE SHOP DI KOTA DENPASAR
}

\author{
Ida Ayu Putu Eka Erawati Dewi ${ }^{1}$ \\ Ni Made Rastini \\ ${ }^{1,2}$ Fakultas Ekonomi dan Bisnis Universitas Udayana, Bali, Indonesia \\ e-mail: geklita.geklita@yahoo.co.id
}

\begin{abstract}
ABSTRAK
Tujuan penelitian ini adalah untuk mengetahui anteseden niat membeli produk kosmetik ramah lingkungan the face shop di kota Denpasar. Penelitian ini dilakukan di Kota Denpasar. Jumlah sampel yang diambil sebanyak 100 sampel dengan metode purposive sampling. Pengumpulan data dilakukan dengan kuesioner dengan skala Likert 1-5. Teknik analisis yang digunakan adalah analisis Regresi Linier Berganda. Berdasarkan hasil analisis ditemukan bahwa nilai pelanggan berpengaruh positif signifikan terhadap sikap, sikap berpengaruh positif signifikan terhadap niat membeli, norma subjektif berpengaruh positif signifikan terhadap niat membeli dan kontrol perilaku berpengaruh positif signifikan terhadap niat membeli. The face shop sebaiknya membangun hubungan yang baik dengan konsumen dengan cara menjadi pendengar dan memberikan solusi kebutuhan kosmetik konsumen. Strategi yang bisa diterapkan the face shop untuk meningkatkan niat membeli konsumen adalah bisa melakukan promosi kedalam target spesifik pelanggan setiap bulan atau mengunakan voucher.
\end{abstract}

Kata kunci: nilai pelanggan, sikap, norma subjektif, kontrol perilaku, niat membeli

\begin{abstract}
The purpose of this study was to find out the antecedents of the intention to buy the face shop environmentally friendly cosmetic products in the city of Denpasar. This research was conducted in Denpasar City. The number of samples taken was 100 samples using the purposive sampling method. Data collection was done by questionnaire with a 1-5 Likert scale. The analysis technique used is the analysis of Multiple Linear Regression. Based on the results of the analysis it was found that customer value had a significant positive effect on attitudes, attitudes had a significant positive effect on purchase intention, subjective norms had a significant positive effect on purchase intention and behavioral control had a significant positive effect on purchase intention. The face shop should build good relationships with consumers by becoming a listener and providing solutions to consumer cosmetic needs. The strategy that can be applied to the face shop to increase the intention to buy consumers is to be able to carry out promotions into customer specific targets every month or use vouchers.
\end{abstract}

Keywords: customer value, attitude, subjective norms, behavioral control, purchase intention 


\section{PENDAHULUAN}

Wanita adalah makhluk yang identik dengan keindahan, wanita selalu ingin tampil cantik dalam berbagai keadaan dan selalu ingin menjadi pusat perhatian bagi sekelilingnya. Oleh karena itu, wanita senang mempercantik diri dengan menggunakan berbagai macam kosmetik yang digunakan. Kondisi ini sangat dimanfaatkan oleh produsen kosmetik. Jumlah penduduk sekitar 250 juta jiwa, menjadikan Indonesia pasar yang menjanjikan bagi perusahaan kosmetik. Kendati mayoritas industri kosmetik membidik target konsumen utama kaum wanita, belakangan mulai berinovasi dengan produk-produk untuk pria.

Kementerian Perindustrian menyebutkan nilai industri ini ditaksir bisa mencapai Rp.100 triliun. Euromonitor International juga memprediksi bahwa Indonesia dan Vietnam akan menjadi pasar kosmetik yang paling cepat bertumbuh di kawasan Asia, mengalahkan China dan India. Euromonitor International bahkan memprediksi laju pertumbuhan majemuk tahunan (Compound Annual Growth Rate), biasanya disingkat CAGR, untuk pasar kosmetik Indonesia dari 2013-2018 berada di atas 9\%. Pembangunan industri ke depan juga akan difokuskan kepada 11 kelompok industri, diantaranya adalah industri farmasi, kosmetik, dan alat kesehatan (www.id.linkedin.com, di akses tanggal 5 Nopember 2017).

Industri saat ini diharapkan peduli terhadap lingkungan. Kerusakankerusakan lingkungan hidup saat ini sudah semakin parah dan telah memancing keprihatinan. Kerusakan mengarah pada degradasi lingkungan, meskipun tidak mencapai tingkatan yang membahayakan, tetapi sudah mencapai pada tingkatan yang menurunkan kualitas bumi sebagai tempat tinggal (Ardianti et al., 2008). 
Didorong oleh kesadaran akan pelestarian lingkungan, masyarakat menuntut produsen tidak hanya memperhatikan atribut pemasaran, tetapi juga menuntut produsen peduli terhadap lingkungan seperti proses produksi yang memperhatikan dampak sosial, kesehatan dan ekologis, distribusi suatu produk (Harris, 2006).

Kemampuan perusahaan dalam memahami konsumen beserta perilaku pembeliannya merupakan salah satu kunci kesuksesan penjualan suatu produk. Sebelum seseorang melakukan tindakan pembelian, ada suatu sikap, yaitu aktivitas mental yang mendahuluinya dan dikenal dengan niat beli. Anoraga (2010:228) mendefinisikan niat beli merupakan suatu proses pengambilan keputusan yang dilakukan oleh konsumen atas produk yang ditawarkan atau yang dibutuhkan. Barr (2007) menyatakan bahwa niat beli adalah keinginan untuk memiliki produk. Menurut Azjen (1991) menjelaskan bahwa niat individu menggunakan suatu produk atau jasa dipengaruhi oleh faktor-faktor yang terdapat dalam Theory of planned behavior (TPB). TPB merupakan kerangka berpikir konseptual yang bertujuan untuk menjelaskan determinan prilaku tertentu. Adapun faktor-faktor yang mempengaruhi niat beli konsumen dalam TPB adalah sikap, norma subyektif dan kontrol perilaku.

Menurut Suprapti (2010:135), sikap adalah suatu ekspresi yang merefleksikan perasaan ketidaksukaan atau kesukaan seseorang terhadap suatu objek melalui proses psikologis sehingga dapat disimpulkan dari apa yang dikatakan atau dilakukannya. Sikap berbeda dengan perilaku, sikap menghadirkan suatu kesiapsiagaan untuk tindakan yang mengarah pada perilaku (Lubis, 2010:78). 
Wang dan Chih-Ching (2014) menemukan hasil bahwa sikap mempengaruhi niat beli konsumen secara positif signifikan. Pernyataan tersebut didukung oleh Tung dan Mei-Fang (2014) dalam penelitiannya yang mengembangkan TPB untuk memprediksi niat beli konsumen menyimpulkan bahwa sikap memainkan peran penting dalam menentukan niat atau tidaknya konsumen dalam membeli suatu produk. Kurniawan et al. (2013) dalam penelitiannya juga menunjukan bahwa sikap memberikan pengaruh positif terhadap minat pembelian suatu produk.

Sikap dipengaruhi oleh nilai pelanggan dalam melakukan pembelian suatu produk (Nepomuceno dan Juliana, 2010). Nilai pelanggan Menurut Gale (1994) bahwa persepsi konsumen terhadap nilai atas kualitas yang ditawarkan relatif lebih tinggi dari pesaing akan mempengaruhi tingkat loyalitas konsumen, semakin tinggi persepsi nilai yang dirasakan oleh pelanggan, maka semakin besar kemungkinan terjadinya hubungan (transaksi). Sedangkan menurut Kotler (2009:34) Nilai yang diterima pelanggan adalah selisih antara total jumlah nilai bagi pelanggan dan total jumlah biaya pelanggan.

Kotler (2009:6) menyatakan bahwa inti pemasaran adalah menciptakan nilai pelanggan lebih baik dari nilai yang diciptakan oleh pesaing. Nilai pelanggan berkaitan dengan penggunaan sebuah produk dan lebih merupakan sesuatu yang dirasakan pelanggan daripada penjual. Nilai pelanggan merupakan persepsi dan apa yang dirasakan pelanggan dan evaluasinya terhadap atribut produk dan kinerjanya, konsekuensi yang timbul setelah mengkonsumsi produk yang pada akhirnya akan membuat pelanggan mencapai tujuannya dalam berbagai situasi pemakaian (Woodruff, 1997:141). 
Bamberg (2003) menjelaskan anteseden niat beli produk organik atau ramah lingkungan. Hasil penelitiannya menemukan bahwa nilai pelanggan sebagai anteseden dari sikap. Pernyataan tersebut didukung oleh Nepomuceno dan Juliana (2010) yang mengatakan bahwa nilai pelanggan mempengaruhi sikap konsumen dalam melakukan pembelian secara positif dan signifikan. Hasil penelitian serupa juga ditunjukkan oleh Mahesh (2013), Recker dan Bilal (2014), Beng (2014) dan Altaf (2017).

Fishbein dan Ajzen (2010:45) mendefinisikan norma subyektif sebagai persepsi tentang apakah orang penting bagi individu berpikir perilaku harus dilakukan. Menurut Ajzen (2007:10), jika individu merasa itu adalah hak pribadinya untuk menentukan apa yang akan dia lakukan dan dapat ditentukan oleh orang lain disekitarnya, maka dia akan merasa bahwa pandangan orang tentang perilaku yang akan dilakukannya adalah sesuai, sehingga akan menimbulkan niat untuk membeli suatu produk.

Choi et al. (2013) menemukan hasil yang positif signifikan antara norma subyektif terhadap niat beli. Hasil penelitian tersebut diperkuat oleh Son dan Byoungho (2013) bahwa norma subyektif mampu mempengaruhi niat konsumen dalam membeli suatu produk. Pengaruh positif norma subyektif terhadap niat beli konsumen juga ditunjukkan oleh Tung dan Mei-Fang (2014), Al-Attas et al. (2015), dan Chen et al. (2016).

Kontrol perilaku mempengaruhi niat beli ditunjukkan oleh penelitian Duarte dan Suzanne (2015). Fishbein dan Ajzen (2010:75) mendefiniskan kontrol perilaku sebagai persepsi seseorang terhadap hambatan dalam melakukan suatu perilaku. 
Kontrol perilaku mempengaruhi niat didasarkan atas asumsi bahwa kontrol keprilakuan yang dipersepsikan oleh individu akan memberikan implikasi motivasi pada orang tersebut (Ajzen, 2007:33).

Angelina dan Edwin (2014) meneliti hubungan antara kontrol perilaku terhadap niat beli menemukan dalam hasil penelitiannya bahwa kontrol perilaku berpengaruh positif dan signifikan terhadap niat beli konsumen. Hal ini menunjukkan bahwa kontrol perilaku merupakan keyakinan bahwa individu pernah melaksanakan perilaku tertentu, kemudian individu melakukan estimasi atas kemampuan dirinya apakah dia punya kemampuan untuk melaksanakan perilaku itu. Beberapa bukti empiris yang menyatakan bahwa kontrol perilaku berpengaruh positif terhadap niat beli konsumen ditunjukkan oleh Tung dan Mei-Fang (2014), Al-Attas et al. (2015), dan Chen et al. (2016).

Beberapa hasil penelitian menyatakan bahwa nilai pelanggan tidak memberikan pengaruh terhadap sikap. Seperti yang dikatakan oleh Hamid et al., (2012) dan Hamid (2014) yang berturut-turut melakukan menyatakan hasil nilai pelanggan tidak mempengaruhi sikap. Hal tersebut juga didukung oleh Maria dan Irene (2008).

Sikap tidak selalu memberikan pengaruh terhadap niat beli konsumen. Seperti yang dilakukan oleh Taylor \& Todd (1995) dan Somohardjo (2012) serta Rajagopal et al., (2016) yang menyebutkan bahwa sikap tidak memiliki pengaruh terhadap niat beli, baik konsumen yang berpengalaman maupun yang tidak berpengalaman. Sikap juga tidak dapat dipengaruhi oleh nilai pelanggan. Berbeda dengan penelitipeneliti yang menyatakan bahwa nilai pelanggan mempengaruhi sikap konsumen 
secara positif dan signifikan, Hamid et al., (2012) dan Hamid (2014) secara berturut turut melakukan penelitian. Ia menemukan hasil bahwa nilai pelanggan atau nilai konsumen tidak secara signifikan mampu mempengaruhi sikap konsumen dalam menentukan pembelian. Pernyataan tersebut telah mendukung penelitian yang dilakukan oleh Maria dan Irene (2008) yang memiliki hasil serupa.

Norma subyektif juga tidak selalu memberi pengaruh yang signifikan terhadap niat beli. Penelitian yang dilakukan oleh Juwaheer et al.,(2012) memberikan hasil yang berpengaruh negatif. Penelitian tersebut sejalan dengan penelitian yang dilakukan oleh Maichum et al., (2016) dan Oktapiani (2017), menunjukan bahwa norma subjektif tidak berpengaruh signifikan terhadap minat beli konsumen. Kontrol perilaku ternyata juga ditemukan tidak sejalan dengan TPB dan para peneliti yang lain.

Kontrol perilaku juga tidak selalu mempengaruhi niat beli secara signifikan. Peneliti terdahulu Chiou (1998) mengatakan bahwa kontrol perilaku tidak mempengaruhi niat beli konsumen. Hasil tersebut juga didukung oleh Afendi et al., (2014) dan Al-Nahdi et al., (2015).

Berdasarkan beberapa penelitian tersebut terlihat bahwa ada ketidak konsistenan terhadap hasil dalam setiap penelitian. Penelitian ini dibuat untuk kembali mengukur faktor yang mempengaruhi niat beli produk.

The face Shop merupakan perusahaan yang sudah terkenal sebagai pelopor ramah lingkungan dalam industri kosmetik selain The Body Shop. The Face Shop juga merupakan perusahaan multinasional yang berkerja sama dengan AMI, perusahaan asal Prancis yang terkenal dengan produk-produk yang natural dan 
ramah lingkungan. The Face Shop sudah ada di Indonesia sejak tahun 2005 dengan produknya yang meliputi perawatan kulit dan tubuh, perawatan mandi, make-up, dan perawatan rambut wanita (www.thefaceshop.com, di akses tanggal 4 Nopember 2017).

Berdasarkan data yang diperoleh, terdapat penjualan produk kosmetik yang tidak menentu setiap bulannya. Secara rinci, informasi tersebut dapat dilihat pada Tabel 1 berikut.

Tabel 1.

Target Penjualan Pertumbuhan Produk The Face Shop Tahun 2016 (Januari-September)

\begin{tabular}{ccc}
\hline Bulan & Penjualan 2016 (Rp) & $\begin{array}{c}\text { Pertumbuhan } \\
(\boldsymbol{\%})\end{array}$ \\
\hline Januari & 228.000 .000 & - \\
Februari & 231.000 .000 & 0,22 \\
Maret & 186.000 .000 & $(3,3)$ \\
April & 169.000 .000 & $(1,25)$ \\
Mei & 223.000 .000 & 3,96 \\
Juni & 184.000 .000 & $(2,85)$ \\
Juli & 234.000 .000 & 3,66 \\
Agustus & 184.000 .000 & $(3,66)$ \\
September & 213.000 .000 & 2,12 \\
Total & $\mathbf{1 . 3 6 5 . 0 0 0 . 0 0 0}$ & \\
\hline
\end{tabular}

Sumber: Data diolah, 2018

Tabel 1 menunjukkan bahwa tingkat penjualan produk the face shop dikatagorikan masih rendah. Dilihat dari tingkat pertumbuhan setiap bulannya masih tidak konsisten, bahkan pada bulan Maret, April, Juni dan Agustus pertumbuhannya justru mengalami penurunan. Hal ini mengindikasikan bahwa masih rendahnya keinginan konsumen untuk memiliki produk kosmetik ramah lingkungan the face shop. Penjualan tertinggi ada pada pertengahan tahun 2016 yaitu bulan Mei. Aktifitas penjualan banyak dipengaruhi oleh faktor tertentu yang dapat meningkatkan aktifitas perusahaan. Menurut Basu (2007:406), banyak yang 
mempengaruhi pertumbuhan penjualan produk salah satunya adalah kondisi pasar terkait keinginan dan kebutuhan konsumen.

Schiffman dan Kanuk (2004:25), menjelaskan bahwa kesadaran akan kebutuhan merupakan hal yang dapat menimbulkan minat beli konsumen akan suatu produk. Berdasarkan Tabel 1 maka diindikasikan niat beli konsumen terhadap produk ramah lingkungan The Face Shop tidak stabil dalam kurun waktu 1 tahun sehingga berakibat pada ketidakstabilan pertumbuhan penjualan produk.

Penelitian ini menggunakan variabel nilai pelanggan, sikap, norma subyektif dan kontrol perilaku sebagai prediktor atau anteseden keputusan pembelian karena variabel-variabel tersebut telah lama diteliti oleh peneliti sebelumnya dengan obyek penelitian yang beragam. Anteseden secara kronologis terjadi sebelum variabel bebas dan variabel terikat yaitu niat membeli, namun anteseden juga dapat berperan sebagai variabel bebas dan sebagai sebab dari adanya akibat. Sehingga tema penelitian diangkat untuk mengetahui sebab-sebab atau faktor-faktor yang mempengaruhi terjadinya peningkatan niat membeli konsumen khususnya terhadap produk ramah lingkungan The Face Shop.

Fishbein (dalam Eagly dan Chaiken, 1993) mengungkapkan bahwa dalam theory of reasoned action membatasi pada kelompok perilaku yang bisa dikatakan volitional atau voluntary, yaitu perilaku yang dilakukan orang karena mereka telah memutuskan untuk berperilaku. Pembatasan ini mempunyai konsekuensi karena perilaku yang membutuhkan keterampilan, sumber daya, dan kesempatan yang tidak tersedia bukan perilaku yang volitional sepenuhnya. 
Fishbein juga memilih untuk tidak memberikan ruang pada kemungkinan bahwa sikap kadang-kadang menimbulkan perilaku yang tidak melibatkan pikiran. Perilaku tersebut bisa saja terjadi, misalnya kebencian terhadap kelompok ras atau etnis, menimbulkan kekerasan yang tiba-tiba dan spontan atau kesukaan pada suatu produk tertentu menimbulkan perilaku yang dikenal impuls buying. Fishbein membatasi modelnya pada perilaku volitional, sehingga Fishbein juga tidak menyertakan perilaku yang mungkin timbul dan bebas dari sikap karena sudah merupakan kebiasaan.

Theory of planned behavior menganggap bahwa teori sebelumnya tidak menjelaskan mengenai perilaku yang tidak dapat dikendalikan sepenuhnya oleh individu, melainkan juga dipengaruhi oleh factor non motivasional yang dianggap sebagai kesempatan atau sumber daya yang dibutuhkan agar perilaku dapat dilakukan. Sehingga dalam teorinya, Ajzen menambahkan satu determinan lagi, yaitu kontrol perilaku, yaitu persepsi mengenai mudah atau sulitnya suatu perilaku dilakukan. Oleh karena itu, menurut theory of planned behavior, intense atau niat membeli dipengaruhi oleh tiga hal yaitu sikap, norma subyektif dan kontrol perilaku (Fishbein dan Ajzen, 1991:134).

Banyak variabel yang mungkin berhubungan atau mempengaruhi kepercayaan yang dipegang seseorang, seperti: umur, jenis kelamin, etnis status soial ekonomi, pendidikan, kebangsaan, agama, keanggotaan, kepribadian, suasana hati, emosi, sikap dan nilai secara umum, inteligensi, anggota kelompok tertentu, pengalaman masa lalu, paparan informasi, dukungan sosial, kemampuan coping, dan lainnya. 
Seseorang tumbuh dalam lingkungan sosial yang berbeda dan membutuhkan informasi tentang beberapa hal, informasi yang diperoleh mendasari keyakinan mereka tentang konsekuensi suatu perilaku, tentang harapan normatif dari lingkungan sosial, dan juga tentang hambatan yang dapat mencegah mereka untuk membentuk perilaku berdasarkan intense yang dimilikinya.

Bamberg (2003) menjelaskan anteseden niat beli produk organik atau ramah lingkungan. Hasil penelitiannya menemukan bahwa nilai pelanggan sebagai anteseden dari niat membeli konsumen. Pernyataan tersebut didukung oleh hasil penelitian berikutnya yang dilakukan oleh Nepomuceno dan Juliana (2010) yang mengatakan bahwa nilai pelanggan mempengaruhi sikap konsumen dalam melakukan pembelian secara positif dan signifikan. Hasil penelitian serupa juga ditunjukkan oleh Mahesh (2013), Recker dan Bilal (2014), Beng (2014) dan Altaf (2017). Namun berbeda dengan Hamid et al., (2012) dan Hamid (2014) yang secara berturut turut menyatakan pada hasil penelitiannya bahwa nilai pelanggan tidak mempengaruhi sikap secara signifikan. Pernyataan Hamid didukung oleh peneliti lain yang menunjukkan hasil serupa yang dilakukan oleh Maria dan Irene (2008). Untuk menguji ketidakpastian hasil penelitian tersebut, maka sesuai Theory of Plan Behavior dirumuskan hipotesis pertama sebagai berikut.

$\mathrm{H}_{1} \quad$ : Nilai pelanggan berpengaruh positif dan signifikan terhadap sikap calon konsumen pada produk kosmetik ramah lingkungan the face shop

Penelitian sebelumnya yang dilakukan oleh Wang dan Chih-Ching (2014) menemukan hasil bahwa sikap mempengaruhi niat beli konsumen secara positif signifikan. Pernyataan tersebut didukung oleh Tung dan Mei-Fang (2014) dalam 
penelitiannya yang mengembangkan Theory of Planned Behavior untuk memprediksi niat beli konsumen menyimpulkan bahwa sikap memainkan peran penting dalam menentukan niat atau tidaknya konsumen dalam membeli suatu produk. Hasil penelitian serupa juga ditunjukkan oleh Al-Attas et al. (2015), Duarte dan Suzanne (2015) serta Chen et al. (2016). Namun berbeda dengan Taylor \& Todd (1995) dan Sumohardjo (2012) yang menyatakan pada hasil penelitiannya bahwa sikap tidak mempengaruhi niat membeli secara signifikan. Pernyataan tersebut juga didukung oleh Rajagopal et al., (2016:35). Untuk menguji ketidakpastian hasil penelitian tersebut, maka sesuai Theory of Plan Behavior dirumuskan hipotesis kedua sebagai berikut.

$\mathrm{H}_{2}$ : Sikap berpengaruh positif dan signifikan terhadap niat beli calon konsumen pada produk kosmetik ramah lingkungan the face shop

Banyak peneliti sebelumnya menghubungkan norma subyektif dengan niat membeli konsumen. Choi et al. (2013) dalam penelitiannya menemukan hasil yang positif signifikan antara norma subyektif terhadap niat beli. Hasil penelitian tersebut diperkuat oleh Son dan Byoungho (2013) bahwa norma subyektif mampu mempengaruhi niat konsumen dalam membeli suatu produk. Pengaruh positif norma subyektif terhadap niat beli konsumen juga ditunjukkan oleh Tung dan MeiFang (2014), Al-Attas et al. (2015), dan Chen et al. (2016). Namun berbeda dengan Juwaheer et al. (2012) yang menyatakan pada hasil penelitiannya bahwa norma subyektif tidak mempengaruhi niat membeli secara signifikan. Pernyataan tersebut didukung oleh peneliti berikutnya yang memiliki hasil serupa yaitu Maichum et al. (2016) dan Oktapiani (2017). Untuk menguji ketidakpastian hasil penelitian 
tersebut, maka sesuai Theory of Plan Behavior dirumuskan hipotesis ketiga sebagai berikut.

$\mathrm{H}_{3}$ : Norma subyektif berpengaruh positif dan signifikan terhadap niat beli calon konsumen pada produk kosmetik ramah lingkungan the face shop

Kontrol perilaku mempengaruhi niat beli ditunjukkan oleh penelitian Duarte dan Suzanne (2015). Peneliti terdahulu berikutnya yang meneliti hubungan antara kontrol perilaku terhadap niat beli yaitu Angelina dan Edwin (2014) menemukan dalam hasil penelitiannya bahwa kontrol perilaku berpengaruh positif dan signifikan terhadap niat beli konsumen. Hal ini menunjukkan bahwa kontrol perilaku merupakan keyakinan bahwa individu pernah melaksanakan perilaku tertentu, kemudian individu melakukan estimasi atas kemampuan dirinya apakah dia punya kemampuan untuk melaksanakan perilaku itu. Beberapa bukti empiris yang menyatakan bahwa kontrol perilaku berpengaruh positif terhadap niat beli konsumen ditunjukkan oleh Tung dan Mei-Fang (2014), Al-Attas et al. (2015), dan Chen et al. (2016). Namun berbeda dengan Chou (1998) yang menyatakan pada hasil penelitiannya bahwa kontrol perilaku tidak mempengaruhi niat membeli secara signifikan. Lebih lanjut, hasil Chou tersebut didukung oleh peneliti yang menyatakan memiliki hasil serupa yaitu Afendi et al., (2014) dan Al-Nahdi et al., (2015). Untuk menguji ketidakpastian hasil penelitian tersebut, maka sesuai Theory of Plan Behavior dirumuskan hipotesis keempat sebagai berikut.

$\mathrm{H}_{4}$ : Kontrol perilaku berpengaruh positif dan signifikan terhadap niat beli calon konsumen pada produk kosmetik ramah lingkungan the face shop 


\section{METODE PENELITIAN}

\section{Tabel 2.}

Variabel dan Indikator Penelitian

\begin{tabular}{lrll}
\hline \multicolumn{1}{c}{ Variabel } & \multicolumn{1}{c}{ Indikator } & \multicolumn{1}{c}{ Sumber } \\
\hline Niat Membeli (Y2) & 1. & $\begin{array}{l}\text { Berniat melalukan pembelian } \\
\text { Niat beli merupakan minat }\end{array}$ & $\begin{array}{l}\text { Angelina dan Edwin } \\
\text { yang dimiliki konsumen }\end{array}$ \\
$\begin{array}{l}\text { untuk membeli produk } \\
\text { 2. }\end{array}$ & $\begin{array}{l}\text { Memenuhi kebutuhan dengan } \\
\text { membeli produk } \\
\text { 3. }\end{array}$ & \\
& Tetap melakukan pembelian & \\
produk & Melakukan pembelian dengan & \\
Sikap (Y1) & jumlah yang relatif sama & \\
Sikap merupakan ekspresi & 1. & Sikap kognitif & Schiffman dan Kanuk \\
perasaan yang & 2. & Sikap afektif & (2008)
\end{tabular}
menggambarkan apakah calon konsumen senang atau tidak Nilai Pelanggan (X1) Nilai pelanggan adalah persepsi konsumen terhadap nilai atas kualitas yang ditawarkan relatif lebih tinggi dari pesaing akan mempengaruhi tingkat loyalitas konsumen, semakin tinggi persepsi nilai yang dirasakan oleh pelanggan, maka semakin besar kemungkinan terjadinya hubungan (transaksi). Norma Subyektif (X2) Norma subjektif adalah sejauh mana calon konsumen memiliki motivasi untuk mengikuti pandangan orang lain terhadap perilaku yang akan dilakukannya Kontrol Perilaku (X3) Kontrol perilaku yaitu fungsi dari keyakinan pengendalian dan pencapaian faktor pengendalian
1. Emotional value
2. Social Value
3. Performance Value
4. Price/value of money

Tjiptono (2005:38)

Angelina dan Edwin (2008)
1. Keluarga dapat mempengaruhi perilaku

2. Temandapat mempengaruhi perilaku

3. Rekan kerjadapat mempengaruhi perilaku

1. Calon konsumen tidak bergantung pada siapapun

2. Kapan saja calon konsumen bisa membeli

3. Tidak ada halangan untuk membeli

Sumber: Data diolah, 2018

Ruang lingkup penelitian ini adalah bidang manajemen pemasaran, khususnya mengenai anteseden niat pembelian. Penelitian ini dilakukan di Kota Denpasar. Populasi dari penelitian ini adalah seluruh masyarakat yang mengetahui 
produk the face shop. Teknik penentuan sampel yang digunakan dalam penelitian ini adalah Non Probability Sampling dengan metode purposive sampling.

Metode yang digunakan untuk mengumpulkan data adalah dengan menyebarkan kuesioner dengan format berupa pertanyaan-pertanyaan dalam bentuk pernyataan. Isi kuesioner difokuskan pada faktor-faktor yang mempengaruhi niat membeli yaitu nilai pelanggan, sikap, norma subjektif dan kontrol perilaku.

Analisis regresi sederhana adalah sebuah metode pendekatan untuk pemodelan hubungan antara satu variabel dependen (nilai pelanggan) dan satu variabel independen (sikap). Dalam model regresi, variabel independen menerangkan variabel dependennya. Untuk analisis regresi sederhana dapat dirumuskan sebagai berikut :

$$
\mathrm{Y}=\alpha+\beta_{1} \mathrm{X}_{1}+\varepsilon
$$

Keterangan:

$$
\begin{array}{ll}
\mathrm{Y} & : \text { Sikap } \\
\alpha & : \text { Konstanta } \\
\mathrm{X}_{1} & : \text { Nilai pelanggan } \\
\beta_{1} & : \text { Koefesien Regresi } \\
\varepsilon & : \text { Error Term }
\end{array}
$$

Analisis regresi linier berganda adalah alat untuk meramalkan pengaruh dua variabel bebas atau lebih terhadap satu variabel terikat. Dalam penelitian ini kegunaan analisis regresi linier berganda bertujuan untuk mengetahui pengaruh sikap, norma subyektif dan kontrol perilaku terhadap niat membeli. Untuk analisis regresi berganda dapat dirumuskan sebagai berikut :

$$
Y=\alpha+\beta_{1} X_{1}+\beta_{2} X_{2}+\beta_{3} X_{3}+\varepsilon
$$


Keterangan:

$$
\begin{array}{ll}
\mathrm{Y} & : \text { Niat membeli } \\
\alpha & : \text { Konstanta } \\
\mathrm{X}_{1} & : \text { Sikap } \\
\mathrm{X}_{2} & : \text { Norma subjektif } \\
\mathrm{X}_{3} & : \text { Kontrol perilaku } \\
\mathrm{B}_{123} & : \text { Koefesien Regresi } \\
\varepsilon & : \text { Error Term }
\end{array}
$$

\section{HASIL DAN PEMBAHASAN}

Model analisis regresi linear sederhana digunakan untuk mendapat koefisien regresi yang akan menentukan apakah hipotesis yang dibuat akan diterima atau ditolak. Hasil analisis ini mengacu pada hasil pengaruh nilai pelangan terhadap sikap. Adapun hasil analisis regresi dengan program Statitical Pacage of Social Science (SPSS) versi 21.0 for Windows dapat dilihat pada Tabel 3 berikut.

Tabel 3.

Rangkuman Hasil Analisis Regresi Linear Nilai Pelanggan Terhadap Sikap

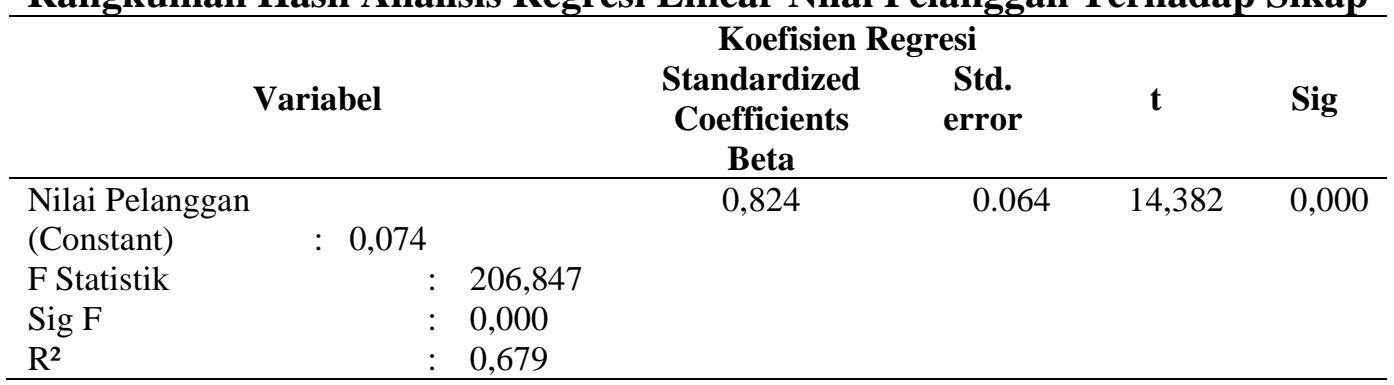

Sumber: Data diolah, 2018

Berdasarkan Tabel 3 dapat ditulis persamaan sebagai berikut.

$\mathrm{Y}=\mathrm{a}+\mathrm{bX}$

$\mathrm{Y}=0.074+0,824 \mathrm{X}$

Dimana

$\mathrm{Y}=$ sikap

$\mathrm{X}=$ nilai pelanggan 
Konstanta sebesar 0,824 menunjukkan bahwa nilai pelanggan berpengaruh positif terhadap sikap. Artinya semakin tinggi nilai pelanggan terhadap produk kosmetik ramah lingkungan the face shop, maka sikap pelanggan terhadap produk tersebut juga akan meningkat.

Model analisis regresi linear berganda digunakan untuk mendapat koefisien regresi yang akan menentukan apakah hipotesis yang dibuat akan diterima atau ditolak. Hasil analisis ini mengacu pada hasil pengaruh sikap, norma subjektif dan kontrol perilaku terhadap niat membeli calon konsumen. Adapun hasil analisis regresi dengan program Statitical Pacage of Social Science (SPSS) versi 21.0 for Windows dapat dilihat pada Tabel 4 berikut.

Tabel 4.

Rangkuman Hasil Analisis Regresi Linear Berganda

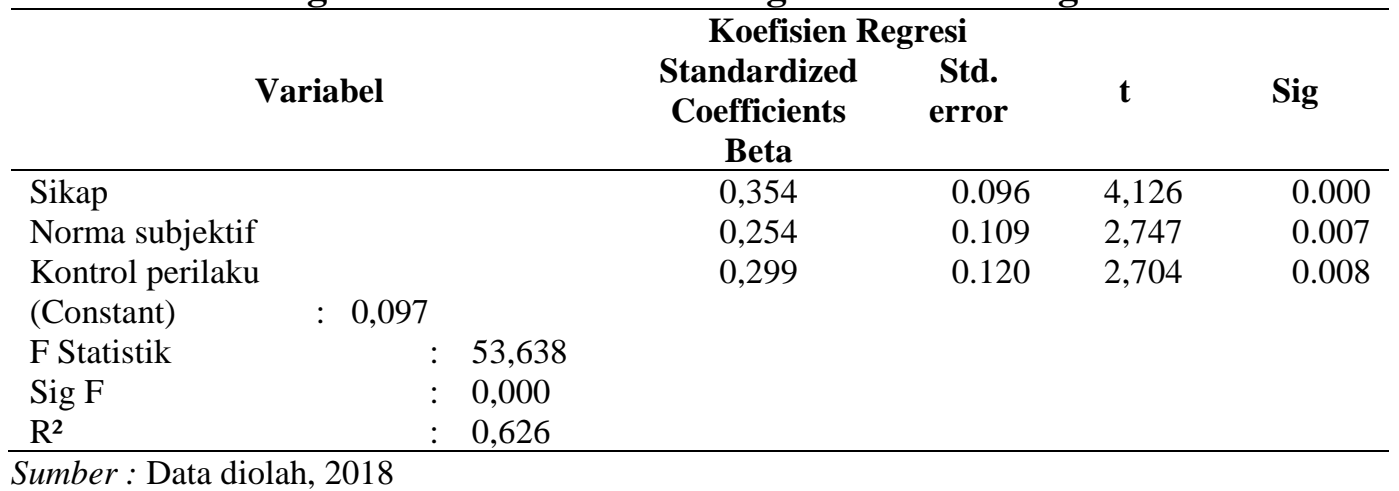

Berdasarkan Tabel 4 dapat ditulis persamaan regresi linear berganda sebagai berikut.

$$
Y=0,097+0,354 X_{1}+0,254 X_{2}+0,299 X_{3}
$$

Dimana

$\mathrm{Y}=$ niat membeli

$\mathrm{X}_{1}=$ sikap

$\mathrm{X}_{2}=$ norma subjektif

$\mathrm{X}_{3}=$ kontrol perilaku 
Persamaan regresi linear berganda tersebut menunjukkan arah masingmasing variabel bebas terhadap variabel terikatnya. Persamaan regresi linear berganda tersebut dapat diuraikan sebagai berikut $X_{1}=+0,354$, menunjukkan bahwa sikap berpengaruh positif terhadap niat membeli produk the face shop, artinya semakin tinggi sikap pelanggan terhadap produk kosmetik ramah lingkungan the face shop, maka niat membeli produk tersebut akan tinggi.

$\mathrm{X}_{2}=+0,254$, menunjukkan bahwa norma subjektif berpengaruh positif terhadap niat membeli produk the face shop, artinya semakin tinggi norma subjektif terhadap produk kosmetik ramah lingkungan the face shop, maka niat membeli produk tersebut akan tinggi.

$\mathrm{X}_{3}=+0,299$, menunjukkan bahwa kontrol perilaku berpengaruh positif terhadap niat membeli produk the face shop, artinya semakin tinggi kontrol perilaku terhadap produk kosmetik ramah lingkungan the face shop, maka niat membeli produk tersebut akan tinggi.

$\mathrm{R}^{2}=0,626$ yang berarti bahwa sebesar 62,6 persen minat beli the face shop di kota Denpasar dipengaruhi oleh sikap, norma subjektif dan kontrol perilaku, sedangkan sisanya sebesar 37,4 persen dipengaruhi oleh variabel lainnya di luar model penelitian.

Berikut hasil uji kelayakan model (uji F):

Tabel 5.

\section{Hasil Uji F}

\begin{tabular}{llrrrrr}
\hline Model & & Sum of Squares & df & Mean Square & F & \multicolumn{1}{c}{ Sig. } \\
\hline 1 & Regression & 67.666 & 3 & 22.555 & 53.638 & $.000^{\mathrm{a}}$ \\
& Residual & 40.369 & 96 & .421 & & \\
Total & 108.035 & 99 & & & \\
\hline
\end{tabular}

Sumber: Data diolah, 2018 
Hasil Uji Anova atau ( $F$ test) menunjukkan nilai F hitung sebesar 53,638, dengan signifikansi 0,000 yang probabilitas signifikansi lebih kecil dari alpha 0,05. Ini menunjukkan bahwa sikap, norma subjektif dan kontrol perilaku dapat digunakan untuk memprediksi niat membeli atau dapat dikatakan bahwa sikap, norma subjektif dan kontrol perilaku secara bersama-sama berpengaruh terhadap niat membeli produk the face shop di kota Denpasar. Sehingga model yang digunakan pada penelitian ini adalah layak untuk uji t statistik yang menguji variabel independen secara parsial terhadap variabel dependen.

Pengujian hipotesis pada pengaruh nilai pelanggan terhadap sikap menemukan hasil (Sig. t $0,000<0,05$ ) serta koefisien beta sebesar 0,927 yang menunjukkan bahwa nilai pelanggan berpengaruh positif signifikan terhadap sikap konsumen terhadap produk kosmetik the face shop di kota Denpasar, sehingga hipotesis pertama dalam penelitian ini diterima. Nilai pelanggan lebih menyerukan pada nilai-nilai emosional, sosial, kinerja dan harga dari produk kosmetik the face shop dalam upayanya untuk meningkatkan niat beli masyarakat terhadap produk tersebut.

Pernyataan ini dipertegas secara empirik oleh beberapa hasil penelitian sebelumnya. Bamberg (2003) menjelaskan anteseden niat beli produk organik atau ramah lingkungan. Hasil penelitiannya menemukan bahwa nilai pelanggan sebagai anteseden dari niat membeli konsumen. Pernyataan tersebut didukung oleh hasil penelitian berikutnya yang dilakukan oleh Nepomuceno dan Juliana (2010) yang mengatakan bahwa nilai pelanggan mempengaruhi sikap konsumen dalam melakukan pembelian secara positif dan signifikan. Hasil penelitian serupa juga 
ditunjukkan oleh Mahesh (2013), Recker dan Bilal (2014), Beng (2014) dan Altaf (2017). Namun berbeda dengan Hamid et al. (2012) dan Hamid (2014) yang secara berturut turut menyatakan pada hasil penelitiannya bahwa nilai pelanggan tidak mempengaruhi sikap secara signifikan. Pernyataan Hamid didukung oleh peneliti lain yang menunjukkan hasil serupa yang dilakukan oleh Maria dan Irene (2008).

Pengujian hipotesis pada pengaruh sikap terhadap niat membeli menemukan hasil (Sig. t 0,000<0,05) serta koefisien beta sebesar 0,395 yang menunjukkan bahwa sikap berpengaruh positif signifikan terhadap niat membeli produk kosmetik the face shop di kota Denpasar,sehingga hipotesis kedua dalam penelitian ini diterima. Nilai pelanggan lebih menyerukan pada aspek-aspekkognitif, afektif dan konatif dari produk kosmetik the face shop dalam upayanya untuk meningkatkan niat beli masyarakat terhadap produk tersebut.

Pernyataan ini dipertegas secara empirik oleh beberapa hasil penelitian sebelumnya. Wang dan Chih-Ching (2014) menemukan hasil bahwa sikap mempengaruhi niat beli konsumen secara positif signifikan. Pernyataan tersebut didukung oleh Tung dan Mei-Fang (2014) dalam penelitiannya yang mengembangkan Theory of Planned Behavior untuk memprediksi niat beli konsumen menyimpulkan bahwa sikap memainkan peran penting dalam menentukan niat atau tidaknya konsumen dalam membeli suatu produk. Hasil penelitian serupa juga ditunjukkan oleh Al-Attas et al. (2015), Duarte dan Suzanne (2015) serta Chen et al. (2016).Namun berbeda dengan Taylor \& Todd (1995) dan Sumohardjo (2012) yang menyatakan pada hasil penelitiannya bahwa sikap tidak 
mempengaruhi niat membeli secara signifikan. Pernyataan tersebut juga didukung oleh Rajagopal et al. (2016:35).

Pengujian hipotesis pada pengaruh norma subjektif terhadap niat membeli menemukan hasil (Sig. t $0,007<0,05$ ) serta koefisien beta sebesar 0,299 yang menunjukkan bahwa norma subjektif berpengaruh positif signifikan terhadap niat membeli produk kosmetik the face shop di kota Denpasar, sehingga hipotesis ketiga dalam penelitian ini diterima. Norma subjektif lebih menyerukan pada pengaruh dari lingkungan eksternal calon konsumen dalam upaya meningkatkan niat beli mereka terhadap produk tersebut.

Pernyataan ini dipertegas secara empirik oleh beberapa hasil penelitian sebelumnya. Choi et al. (2013) dalam penelitiannya menemukan hasil yang positif signifikan antara norma subyektif terhadap niat beli. Hasil penelitian tersebut diperkuat oleh Son dan Byoungho (2013) bahwa norma subyektif mampu mempengaruhi niat konsumen dalam membeli suatu produk. Pengaruh positif norma subyektif terhadap niat beli konsumen juga ditunjukkan oleh Tung dan MeiFang (2014), Al-Attas et al. (2015), dan Chen et al. (2016). Namun berbeda dengan Juwaheer et al. (2012) yang menyatakan pada hasil penelitiannya bahwa norma subyektif tidak mempengaruhi niat membeli secara signifikan. Pernyataan tersebut didukung oleh peneliti berikutnya yang memiliki hasil serupa yaitu Maichum et al., (2016) dan Oktapiani (2017).

Pengujian hipotesis pada pengaruh kontrol perilaku terhadap niat membeli menemukan hasil (Sig. t $0,008<0,05$ ) serta koefisien beta sebesar 0,326 yang 
menunjukkan bahwa kontrol perilaku berpengaruh positif signifikan terhadap niat membeli produk kosmetik the face shop di kota Denpasar, sehingga hipotesis keempat dalam penelitian ini diterima. Kontrol perilaku lebih menyerukan pada ketergantungan ataupun hambatan para calon konsumen dalam upaya meningkatkan niat beli mereka terhadap produk tersebut.

Pernyataan ini dipertegas secara empirik oleh beberapa hasil penelitian sebelumnya. Angelina dan Edwin (2014) menemukan dalam hasil penelitiannya bahwa kontrol perilaku berpengaruh positif dan signifikan terhadap niat beli konsumen. Hal ini menunjukkan bahwa kontrol perilaku merupakan keyakinan bahwa individu pernah melaksanakan perilaku tertentu, kemudian individu melakukan estimasi atas kemampuan dirinya apakah dia punya kemampuan untuk melaksanakan perilaku itu. Beberapa bukti empiris yang menyatakan bahwa kontrol perilaku berpengaruh positif terhadap niat beli konsumen ditunjukkan oleh Tung dan Mei-Fang (2014), Al-Attas et al. (2015), dan Chen et al. (2016). Namun berbeda dengan Chou (1998) yang menyatakan pada hasil penelitiannya bahwa kontrol perilaku tidak mempengaruhi niat membeli secara signifikan. Lebih lanjut, hasil Chou tersebut didukung oleh peneliti yang menyatakan memiliki hasil serupa yaitu Afendi et al. (2014) dan Al-Nahdi et al. (2015).

Temuan penelitian ini menunjukkan bahwa nilai pelanggan berpengaruh positif signifikan terhadap sikap. Sikap, norma subjektif dan kontrol perilaku baik secara parsial maupun simultan berpengaruh positif signifikan terhadap niat membeli produk kosmetik ramah lingkungan the face shop. Temuan ini menjawab 
Theory of Plan Behavior yang menyatakan bahwa intense atau niat membeli dipengaruhi oleh tiga hal yaitu sikap, norma subyektif dan kontrol perilaku (Fishbein dan Ajzen, 2010:134). Dengan demikian, hasil penelitian ini mampu memperkaya temuan-temuan studi empiris lainnya terkait topik keadilan organisasional, kepuasan kerja dan komitmen organisasional dari lingkungan organisasi ritel.

Temuan penelitian menjelaskan bahwa niat membeli produk ramah lingkungan khususnya dalam penelitian ini produk kosmetik the face shop dipengaruhi oleh sikap, norma subjektif dan kontrol perilaku. Di sisi lain, sikap dipengaruhi secara signifikan oleh nilai pelangan. Sehingga, untuk meningkatkan niat beli calon konsumen terhadap produk kosmetik the face shop maka nilai pelanggan, sikap, norma subjektif dan kontrol perilaku penting untuk ditingkatkan.

Terkait nilai pelanggan, terdapat 3 indikator yang nilai rata-ratanya dibawah konstruk variabel nilai pelanggan, yaitu komunikasi, perhatian dan keramahan yang ditunjukkan oleh karyawan kepada calon konsumen the face shop. The face shop sebaiknya jangan pernah berpikir calon konsumen adalah target penjualan. Bangunlah hubungan yang baik dengan calon konsumen. Jika hubungan sudah baik, maka produk atau jasa apapun yang kita tawarkan akan terima dengan baik oleh mereka. Jadilah pendengar yang baik bagi calon konsumen. Setelah mendengarkan dengan baik, beri solusi terbaik yang sesuai dengan kebutuhannya. Kendalikan emosi serta gunakan kalimat positif dan jelas karena membuat pendengar atau calon konsumen menjadi senang dan antusias. Dengan begitu besar kemungkinan mereka akan memborong produk kosmetik the face shop. 
Terdapat dua hal penting yang perlu dilakukan the face shop untuk meningkatkan lagi sikap mereka sebelum akhirnya berniat untuk membeli produk kosmetik the face shop. Yaitu perasaan nyaman dan kemudian tetap akan melalukan pembelian kembali. The face shop harus mengenali calon konsumen dengan baik, kemudian terapkan strategi yang pas untuk memuaskan calon konsumen. Strategi yang bisa diterapkan adalah bisa melakukan promosi kedalam target spesifik pelanggan setiap bulan atau mengunakan voucher.

\section{SIMPULAN DAN SARAN}

Berdasarkan permasalahan penelitian, tujuan, hipotesis, dan hasil pembahasan pada bab sebelumnya, maka dapat disimpulkan bahwa nilai pelanggan berpengaruh positif dan signifikan terhadap sikap. Peningkatan nilai pelanggan meningkatkan sikap calon konsumen terhadap produk kosmetik ramah lingkungan the face shop.

Sikap berpengaruh positif dan signifikan terhadap niat membeli. Peningkatan sikap meningkatkan niat membeli calon konsumen terhadap produk kosmetik ramah lingkungan the face shop.

Norma subjektif berpengaruh positif dan signifikan terhadap niat membeli. Peningkatan norma subjektif meningkatkan niat membeli calon konsumen terhadap produk kosmetik ramah lingkungan the face shop.

Kontrol perilaku berpengaruh positif dan signifikan terhadap niat membeli. Peningkatan kontrol perilaku meningkatkan niat membeli calon konsumen terhadap produk kosmetik ramah lingkungan the face shop. 
Berdasarkan hasil penelitian dan kesimpulan, berikut ini beberapa saran untuk meningkatkan niat membeli melalui nilai pelangan, sikap, norma subjektif dan kontrol perilaku adalah nilai pelanggan perlu lebih ditingkatkan lagi dengan meningkatkan cara berkomunikasi yang baik, memberikan perhatian yang baik, dan selalu ramah dengan calon konsumen serta meningkatkan kemudahan cara bertransaksi.

The face shop harus meningkatkan sikap calon konsumen, dari hasil penelitian, hal yang sangat perlu ditingkatkan adalah kenyamanan mereka menggunakan produk the face shop dan membuat mereka tetap membeli produk the face shop dikemudian hari.

The face shop harus memahami apa saja halangan dan hambatan calon konsumen termasuk rekan kerja maupun lingkungan mereka yang bisa mengontrol perilaku mereka dalam menentukan niat mereka membeli produk the face shop.

The face shop harus memahami halangan yang dihadapi calon konsumen untuk membeli produk the face shop karena ditemukan masih terdapat sedikit hambatan yang dirasakan calon konsumen sebelum akhirnya berniat membeli produk the face shop.

\section{REFERENSI}

Ajzen, Icek. (2007). Understanding Attitudes And Predicting Social Behaviour. Englewood Cliffs, NJ: Prentice Hall.

Al-Attas, H. A., Tawfik S. A., Shakeel A. H., Abu H. A. B., Mohammed S. B., and Omar H. G. (2015). The effect of attitude, dimension of subjective norm, and perceived behaviour control, on the intention to purchase real estate in Saudi Arabia. International Journal of Marketing Studies, 7 (5), pp. 120131. 
Altaf, S. N. (2017). Consumption values and consumer attitude towards automobile purchases.A Research Journal of Commerce, Economics and Social Science, 11 (1), pp. 1-5.

Afendi, N.A., Farah L.A., and Aflah I.D. (2014). Determinants of halal purchase intention: Case in Perlis. International Journal of Business and Social Research (IJBSR), 4 (5), pp. 118-123

Al-Nahdi T.S., Emanuel M., Adnan M.B., and Achmat A.J. (2015). Factors affecting purchasing behavior in real estate in Saudi Arabia. International Journal of Business and Social Science, 6 (2), pp. 113-125

Angelina, J. P., dan Edwin J. (2014). Analisis pengaruh sikap, subjective norm dan perceived behavioural control terhadap purchase intention pelanggan SOGO Department Store di Tunjungan Plaza Surabaya. JurnalS trategi Pemasaran, 2 (1), pp. 1-7.

Anoraga, P. (2010).Manajemen Bisnis. Jakarta: PT. RinekaCipta

Ardianti, N. T., Fahmi I., dan Ratnawati A. (2008). Analisis perilaku konsumen bogor terhadap produk kosmetik hijau. Jurnal Manajemen \& Agribisnis, 5 (1), pp. 16-22.

Basu, Swasta dan Irawan. (2008). Manajemen pemasaran modern. Yogyakarta: Liberty

Bamberg, S. (2003). How does environmental concern influence specific environmentally related behavior? A new answer to an old question. Journal of Environmental Psychology, 23 (1), pp. 21-32.

Barr, S. (2007). Factors influencing environmental attitudes and behaviours. Environment and Behaviour, 39 (4), pp. 435-473.

Beng, J. K. S. (2014). The infulence of customer perceived value and attitude toward local supermarket choice. Univeristi Sains Malaysia.

Chen, Ping-Wen, Min-Jhih Cheng, Shiu-Wan Hung, and Her-Her Tsai. (2016). The adoption intentions of mobile applications. Computer and Information Science, 3 (7), pp. 38-42.

Choi, J. G., Eojina K., Sunny H., and IlSun Y. (2013). The role of attitude, subjective norm, and perceived behavioral control in the formation of consumers behavioral intentions to read menu labels in the restaurant industry. International Journal of Hospitality Management, 3 (5), pp. 203213.

Chou, J.S. (1998). The effects of attitude, subjective norm, and perceived behavioral control on consumers' purchase intentions: the moderating 
effects of product knowledge and attention to social comparison information. Proc. Natl. Sci. Counc. ROC (C), 9 (2), pp. 298-308

Duarte, P., and Suzanne A. (2015). An integrative model of consumers intentions to purchase travel online. Tourism Management, 4 (6), pp. 64-79.

Eagly, A. H. and Chaiken. (1993). The psychology of attitude. Forth Worth: Harcout Brace Jovanovich College Publisher

Harris, P. G. (2006). Environmental perspectives and behavior in China: Sinopsis and bibliography. Environmental and Behaviour, 38 (1), pp. 5-21.

Hamid, R.A., Hateem A.G., and Tamkeen Z.S. (2012). Analysis of attitude towards green purchase: pakistan in context. International Journal of Business and Social Science, 3 (6), pp. 112-115

Hamid, R.A. (2014). A Study on the relationship between consumer attitude, perceived value and green products. Iranian Journal of Management Studies (IJMS), 7 (2), pp. 329-342

Juwaheer,Thanika Devi., Sharmila Pudaruth., And PriyashaRamdin .(2012). Factors influencing the adoption of internet banking: a case study of commercial banks in mauritius. World Journal Of Science, Technology And Sustainable Development, 9 (3), Pp. 204-234.

Kurniawan, David .,Prof.Dr. HataneSemuel. S.E., M.Si.,dan Edwin Japarianto, S.E., M.M., .(2013). Analisis penerimaan nasabah terhadap layanan mobile banking dengan menggunakan pendekatan technology acceptance model dan theory of reasoned action. Jurnal Manajemen Pemasaran, 1 (1), Pp. 1-13.

Kotler, P., dan G. Armstrong. (2009). Dasar-dasar pemasaran. Jakarta: PT. Indeks Kelompok Gramedia.

Lubis, A. I. (2010). Akuntansi keprilakuan. Jakarta: Salemba Empat.

Maichum, K., Surakiat P., and Ke-Chung Peng. (2016). Application of the extended theory of planned behavior model to investigate purchase intention of green products among thai consumers. www.mdpi.com/journal/sustainability, pp. $1-20$

Maria-Eugenia R.M., and Irene G.S. (2008). Perceived value, customer attitude and loyalty in retailing. Journal of Retail and Leisure Property, 7 (4), pp. 305314

Mahesh, N. (2013). Consumer's perceived value, attitude and purchase intention of green products. SMS Varanasi, 9 (1), pp. 36-43. 
Nepomuceno, M. V., and Juliana B. P. (2010). Human values and attitudes toward bank services in Brazil. International Journal of Bank Marketing, 28 (3), pp. 168-192.

Oktapiani, Renny .(2017). Interpretasi Model Penerimaan Sistem Ujian Online Dengan Pendekatan Technologi Acceptance Model (TAM) Dan Theory PlannedOf Behavior (TPB) Di SMK Pasim Plus Kota Sukabumi. Swabumi, 5, Pp. 98-107.

Rajagopal, Behl, and Ramesh. (2016). Business analytics and cyber security management in organizations. United States: IGI Global.

Recker, A., and Bilal S. (2014). The effects of consumer knowledge and values on attitudes and purchase intentions: a quantitative studiy of organic personal care products among German female consumers. Umea School of Business

Schiffman dan Kanuk. (2004). Perilaku konsumen. Jakarta:Prentice Hall

Sumohardjo, Nicky. (2017). The effect of online reviews on the review attitude and purchase intention. Tesis Master of Science in Economics \& Business, Erasmus University Rotterdam, Rotterdam

Son, J., and Byoungho J. (2013). Consumers purchase intention toward foreign brand goods. Management Decision, 51 (2), pp. 434-450.

Suprapti, N. W. S. (2010). Perilaku konsumen: pemahaman dasar dan aplikasinya dalam strategi pemasaran. Bali: Udayana University Press

Taylor, S. And Todd, P.A. (1995).Understanding information technology usage: a test of competing models. Information Systems Research, 6 (2), Pp. 14476.

Tjiptono, S. (2005). Pemasaranjasa. Malang: Bayumedia Publishing

Tung, Pei-Ju and Mei-Fang Chen. (2014). Developing an extended theory of planned behaviour model to predict consumers intention to visit green hotels. International Journal of Hospitality Management, 3 (6), pp. 221230.

Wang, Yu-Mei and Chih-ChingTeng. (2014). Decisional factors driving organic food consumption: generation of consumer purchase intentions. British Food Journal, 117 (3), pp. 1066-1081.

Woodruff, Robert B. (1997). Customer value : the next source for competitive advantage. Journal of Academy of Marketing Science. 25 (2), pp.139-153. 